\title{
Effects of Dimethoate on Condition Factor and Organosomatic Indices of Heterobranchus Longifilis (Valenciennes, 1840)
}

\author{
Wilfred-Ekprikpo P.C. \\ Aquaculture Department, Nigerian Institute for Oceanography and Marine Research, 3, Wilmot Point Road, \\ Victoria Island, PMB 12729, Lagos, Nigeria
}

*Corresponding Author: Wilfred-Ekprikpo P.C., Aquaculture Department, Nigerian Institute for Oceanography and Marine Research, 3, Wilmot Point Road, Victoria Island, PMB 12729, Lagos, Nigeria

\begin{abstract}
The effect of sublethal exposure of Heterobranchus longifilis (mean length 27.81+2.09cm; mean weight $386.77 \pm 56.23 \mathrm{~g})$ to different concentrations of dimethoate $(0.00$ - control, 0.25, 0.50, 0.75, and $\left.1.00 \mathrm{mlL}^{-1}\right)$ for 15 days on the behavioural characteristics, condition factor $(K)$ and organosomatic indices such as Renatosomatic index (RSI), Hepatosomatic Index (HSI), Spleenosomatic Index (SSI) and Cardiosomatic (CSI). The results obtained from the study indicated that behavioural reactions such as erratic swimming, body discouloration, jerky movement, surfacing and air gulping were more pronounced in the fish exposed to 0.50-1.00mg/L concentrations of the chemical. However, there was no significant differences $(P>$ $0.05)$ between the initial (K1) and final (K2) condition factor of the exposed fish. In the organosomatic indices used to assess response of fish to the toxicants, significant increases $(P<0.05)$ comparable to the control was observed in RSI, while the values of HSI decreased significantly when compared to the control after 15days. The values of SSI and CSI obtained during the trial were within the same range, as no significant change was observed. Hence, Renatosomatic index (RSI), Hepatosomatic index (HSI), will be a good biomarker to evaluate pollution effect on H.longifilis.
\end{abstract}

Keywords: Aquatic Environment, Catfish, Toxicity, Organosomatic indices, Behavioural response.

\section{INTRODUCTION}

In recent times, pollution has been a most important threat to the sustainability of aquatic environment [1]. The use of chemicals in various agriculture operations have been on the increase especially on the developing countries across the globe [2]. Pesticides can be described as substances that are used for controlling pest in homes and agricultural field. In the recent times, pesticides use is on the increasing trend. As such, pesticides are among the important pollutants of the aquatic ecosystem [3]. Conversely, Gabriel et al. [4] reported that chemicals such as pesticides are among the most potentially harmful chemicals introduced into the aquatic environment through various human activities. Several collections of these pesticides are lethal to the non-targeted organisms especially fish in the aquatic environment [5]. The degree of toxicity of these chemicals depends largely on their compositions, rate and mode of application and as well as the immune system and other metabolic pathways of the target organisms. Apart from these, agrochemicals can also be classified based on target organisms. Classification based on targets organisms includes insecticides, rodenticides, herbicides and fumigants $[6,7]$.

During agricultural operations different brands of chemicals are available for the control of pests such as herbs/weeds or rodents in the field. Some of these pesticides have some level of harmful ecological impacts on the organisms as well as humans that use the substances contaminated by such kind of chemicals unknowingly [8]. Dimethoate (an organophosphrate insecticide) is one of the most frequently used pesticides in the world [9]. Like other organophosphates, dimethoate is an acetylcholinesterase inhibitor which disables cholinesterase, an enzyme essential for central nervous system function. In Nigeria, it is sold in an open market and it is well embraced by farmers. It is mostly used for the control of flies, lice, insect pests (of ornamental plants and food crops, nematodes and soil insects in lawns and croplands [10-11]. Moreover, dimethoate is equally used in both rural and urban centers, its use in urban areas include dormant sprays on fruits trees, professional landscape and pest control services in these areas [12]. 
In the aquatic environment fishes have been widely used as bio-indicator in assessing the degree of pollution. However, lethal and sublethal concentrations of toxicants usually have adverse effect on fish behaviour, histopathology, growth, reproduction, feeding and general physiological developments of exposed organisms [13]. Organosomatic indices can be described as the ratios of organs to body weight [14](Ronald and Bruce, 1990), measured organ in relation to body mass can be directly linked to toxic effects of chemical on target organ[15] (Giullo and Hinton, 2008).Commonly used organosomatic indices in various stress related studies include hepatosomatic index (HIS), viscerosomatic index (VSI), spleenosomatic index (RSI) and Cardiosomatic index (CSI) [16]. The condition factors are used as indicator of the well being of individual organism, because it integrates many levels of the organizational processes. For example, a decrease in condition factor is considered a reflection of depletion in energy reserves because these indices are positively related to muscle and livers energy content $[17,18]$. This research work therefore examines the suitability of somatic indices in H.longifilis as an effective biomarkers of dimethoate induced stress in fish.

\section{Materials AND Methods}

\subsection{Experimental Location and Fish}

The study was carried out in Aqua Green Integrated Aquaculture Center, Eliozu, Port Harcourt, Rivers State, Nigeria. A total of 60 H.longifilis (mean length $27.81 \pm 2.09 \mathrm{~cm}$; mean weight $386.77 \pm 56.23 \mathrm{~g}$ ) were sourced from a fish farm in the State. The fishes were transported in two open 501 containers to the laboratory and acclimated for a period of seven days.

\subsection{Preparation of Test Solutions and Exposure of Fish}

Dimethoate, used in this experiment was purchased from a commercial outlet in Port Harcourt, Nigeria. H.longifilis were exposed to the chemical at the concentrations of 0.00 control, $0.25,0.50$, 0.75 and $1.00 \mathrm{mg} / \mathrm{L}$ in triplicates. Four fish were randomly distributed into each test tank. The experiment lasted for a period of 15 days. The water in the tanks was exchanged on daily basis. The fish were fed two times in a day at $3 \%$ body weight with Vital fish feed.

\subsection{Evaluation of Physico-Chemical Parameters of Water in Experimental Tanks}

During the exposure period which lasted for 15 days, some water quality parameters namely $\mathrm{pH}$, dissolved oxygen, temperature and ammonia were taken daily using the methods described by APHA [19].

\subsection{Behavioral Response}

The behavioral and morphological response of the fish is observed after exposure of the fish to various concentration of the toxicant. The control tank was monitored with the tanks of various concentration of the toxicant, assessing any behavioral or morphological changes. The responses which are air gulping index, opercular ventilation count, tail fin movement, restlessness, erratic swimming, barbell deformation, loss of reflex were recorded from 24hrs-96hrs. [20]

\subsection{Organosomatic Indices}

The organosomatic indices of the liver, heart, kidney and spleen were then calculated for the twenty fish according to Dogan and Can [21] to get the organ weight to the body weight ratios of the fish as follows: $\frac{\text { weight of theorgan }}{\text { weight of the fish }} \times 100$

The initial (K1) and final (K2) condition factor were calculated according to the method of Anderson et al. [22]

Using the formula: $\mathrm{K}=\frac{W \times 100}{L^{3}}$

Where $\mathrm{K}=$ Condition factor $; \mathrm{W}=$ Weight of the fish $; \mathrm{L}=$ Length of the fish 
Effects of Dimethoate on Condition Factor and Organosomatic Indices of Heterobranchus Longifilis (Valenciennes, 1840)

\subsection{Mortality Rates}

Mortality was also recorded from 24 - 96hrs.Mortality was confirmed when the fishes did not respond to repeated external stimuli [22].

\subsection{Data Analysis}

Data obtained from the study were subjected to a one-way analysis of variance (ANOVA) test at $0.05 \%$ probability level, using statistical package for the social sciences (SPSS) version 17 . Where differences among means existed, the Tukey test was used.

\section{RESUlts}

The physicochemical parameters of water in the experimental tanks during the study (Table 1) showed that there were no significant differences between the treatment and the control, except in the values of dissolved oxygen which reduces with increasing concentrations of the chemical. Behavioural responses in the fish exposed to different concentrations of dimethoate. The results obtained from the study indicated that behavioural reactions such as erratic swimming, body discouloration, jerky movement, surfacing and air gulping were more pronounced in the fish exposed to $0.50-1.00 \mathrm{mg} / \mathrm{L}$ of the chemical.The condition factor and organosomatic indices of H.longifilis following dimethoate exposure are presented in Table 3. The changes between the initial (K1) and the final (K2) were not statistically significant $(\mathrm{P}>0.05)$. The exposure of H.longifilis to varying concentration of dimethoate resulted in significant $(\mathrm{P}>0.05)$ increase in RSI and decrease in HSI, when compared to the control values. However, no significant changes were observed in SSI and CSI, they were within the same range with the control value (Table 3).

Table1. Physico-Chemical Parameters of Water in the Exposure Aquaria

\begin{tabular}{|c|c|c|c|c|c|}
\hline $\begin{array}{c}\text { Conc. Of } \\
\text { cypermethrin. } \\
(\mathbf{m l} / \mathbf{L})\end{array}$ & $\mathbf{p H}$ & $\begin{array}{c}\text { Conductivity } \\
\boldsymbol{\mu s} / \mathbf{c m}\end{array}$ & $\begin{array}{c}\text { Dissolved } \\
\text { (Oxygen) } \\
\mathbf{m} / \mathbf{g l}\end{array}$ & $\begin{array}{c}\text { Alkalinity } \\
\mathbf{m g} / \mathbf{l}\end{array}$ & Hardness Mg/1 \\
\hline 0.00 & $6.46 \pm 0.29^{\mathrm{a}}$ & $65.39 \pm 0.99^{\mathrm{a}}$ & $7.87 \pm 0.07^{\mathrm{c}}$ & $29.87 \pm 0.71^{\mathrm{a}}$ & $7.61 \pm 0.45^{\mathrm{a}}$ \\
\hline 0.25 & $6.07 \pm 0.27^{\mathrm{a}}$ & $69.75 \pm 0.75^{\mathrm{a}}$ & $6.50 \pm 0.30^{\mathrm{b}}$ & $28.55 \pm 0.99^{\mathrm{a}}$ & $7.07 \pm 0.01^{\mathrm{a}}$ \\
\hline 0.50 & $5.89 \pm 0.39^{\mathrm{a}}$ & $70.87 \pm 0.82^{\mathrm{a}}$ & $6.29 \pm 0.27^{\mathrm{b}}$ & $28.27 \pm 0.01^{\mathrm{a}}$ & $7.29 \pm 0.77^{\mathrm{a}}$ \\
\hline 0.75 & $5.87 \pm 0.45^{\mathrm{a}}$ & $76.15 \pm 0.55^{\mathrm{a}}$ & $5.08 \pm 0.48^{\mathrm{a}}$ & $28.16 \pm 0.91^{\mathrm{a}}$ & $7.04 \pm 0.88^{\mathrm{a}}$ \\
\hline 1.00 & $5.95 \pm 0.37^{\mathrm{a}}$ & $79.15 \pm 0.02^{\mathrm{a}}$ & $5.55 \pm 0.19^{\mathrm{a}}$ & $28.99 \pm 0.77^{\mathrm{a}}$ & $7.28 \pm 0.09^{\mathrm{a}}$ \\
\hline
\end{tabular}

Mean with different superscript in the same column are not significantly different $(P>0.05)$

Table2. Behavioral characteristics of Heterobranchus longifilis exposed to sub lethal levels of Dimethoate for 15 Days

\begin{tabular}{|l|l|l|l|l|l|}
\hline \multirow{2}{*}{ Characteristics } & \multicolumn{5}{l|}{} \\
\cline { 2 - 7 } & $\mathbf{0 . 0 0}$ & $\mathbf{0 . 2 5}$ & $\mathbf{0 . 5 0}$ & $\mathbf{0 . 7 5}$ & $\mathbf{1 . 0 0}$ \\
\hline Erratic Swimming & - & + & ++ & ++ & +++ \\
\hline Body Discouloration & - & + & ++ & ++ & +++ \\
\hline Jerky movement & - & + & ++ & ++ & +++ \\
\hline Surfacing and Air gulping & - & + & ++ & ++ & +++ \\
\hline Mortality & - & + & ++ & ++ & +++ \\
\hline
\end{tabular}

- Absent $;+$ Low $;++$ Moderate $;+++$ High characterist

Table3. Condition factor and Organosomatic Indices of Heterobranchus longifilis exposed to sub lethal levels of Dimethoate for 15 Days (Mean \pm SD)

\begin{tabular}{|c|c|c|c|c|c|c|}
\hline Conc $(\mathbf{m g} / \mathbf{L})$ & Initial $\left(\mathbf{K}_{\mathbf{1}}\right)$ & Final $\left(\mathbf{K}_{\mathbf{2}}\right)$ & RSI & HSI & SSI & CSI \\
\hline 0.00 & $6.45 \pm 0.45^{\mathrm{a}}$ & $6.41 \pm 0.71^{\mathrm{a}}$ & $0.47 \pm 0.99^{\mathrm{a}}$ & $0.99 \pm 0.03$ & $0.045 \pm 0.01^{\mathrm{a}}$ & $0.080 \pm 0.01^{\mathrm{a}}$ \\
\hline 0.25 & $6.80 \pm 0.25^{\mathrm{a}}$ & $6.92 \pm 0.55^{\mathrm{a}}$ & $0.56 \pm 0.88^{\mathrm{a}}$ & $0.85 \pm 0.02^{\mathrm{a}}$ & $0.070 \pm 0.02^{\mathrm{a}}$ & $0.085 \pm 0.01^{\mathrm{a}}$ \\
\hline 0.50 & $6.10 \pm 0.45^{\mathrm{a}}$ & $5.29 \pm 0.91^{\mathrm{b}}$ & $0.77 \pm 0.47^{\mathrm{b}}$ & $0.70 \pm 0.01^{\mathrm{a}}$ & $0.050 \pm 0.01^{\mathrm{a}}$ & $0.045 \pm 0.01^{\mathrm{a}}$ \\
\hline 0.75 & $6.30 \pm 0.70^{\mathrm{a}}$ & $5.47 \pm 0.45^{\mathrm{b}}$ & $0.81 \pm 1.99^{\mathrm{b}}$ & $0.50 \pm 0.05^{\mathrm{a}}$ & $0.050 \pm 0.02^{\mathrm{a}}$ & $0.085 \pm 0.01^{\mathrm{a}}$ \\
\hline 1.00 & $6.60 \pm 0.85^{\mathrm{a}}$ & $4.01 \pm 0.71^{\mathrm{c}}$ & $0.99 \pm 0.09^{\mathrm{b}}$ & $0.40 \pm 0.05^{\mathrm{a}}$ & $0.040 \pm 0.01^{\mathrm{a}}$ & $0.075 \pm 0.01^{\mathrm{a}}$ \\
\hline
\end{tabular}

Mean with different superscript in the same column are significantly different $(P<0.05)$

Key: K-Condition factor; RSI-Renatosomatic Index; HIS- Hepatosomatic Index; SSI- Spleenosomatic Index; CSI- Cardiosomatic Index 
Effects of Dimethoate on Condition Factor and Organosomatic Indices of Heterobranchus Longifilis (Valenciennes, 1840)

\section{DISCUSSION}

The variations in the mean values of the water quality parameters in the experimental tanks during the trial were minimal throughout the period of study, except in the values of dissolved oxygen. Dissolved oxygen was observed to decrease with increase in the concentration of dimethoate. This was not surprising as Oxygen had been reported to be depressed in polluted and contaminated water bodies. This result agrees with the findings of Gabriel et al. [23] in the experimental tanks of Clarias gariepinus exposed to cypermethrin. The reduction in the values of oxygen may be due to the impact of dimethoate on the concentration of dissolved oxygen, as Oxygen had been reported to be depleted in polluted and contaminated water bodies [24]. However, all the other values of the water quality parameter observed in this study were within the suggested tolerance range of warm water species [25].

The behavioral response of H.longifilis exposed to varying concentration of dimethoate indicated that. Erratic swimming, body discouloration, jerky movement, surfacing and air gulping and mortality were not observed in the control, but their rate increased as the concentration of the toxicant increased. Behavioural response and mortality are some of -the parameters used to examine the early toxicity of a toxicant to fishes. As such when the fishes are stressed they responds through their behaviours [26]. The behavioral changes observed in this study is similar to the one reported by Nte and Akinrotimi [27] in Sarotherodon melanotheron exposed to industrial effluents.Also, sudden quick movement, settling at the bottom and excessive mucus secretion on the skin were also observed. Additionally, fishes showed unusual movement as a result muscle spasm and lethargy [28]. However, Gabriel et al. [29] reported that herbicides containing cypermethrin causes abnormal behaviour in fish: erratic swimming, sudden quick movements and restlessness. These abnormal behavioural responses exhibited by H.longifilis in this present study suggest that they suffered respiratory impairment due to the effect of the toxicant precisely on gills and general metabolism.

Furthermore, the values of condition factor values in the experimental fish were within the same range, however, a slight increase was observed at lower concentrations of dimethoate. It could be that at lower concentrations, the toxicant may have triggered some biochemical responses in the fish such as increased metabolism, blood production and water intake as a coping mechanism which may have induced an apparent improvement in the condition of the fish [21]. However, at higher concentrations of thee chemical, the condition factor of the fish decreased. This may be due to the observed increase in agitated movement and restlessness, reduction in feeding activity, possible loss of ions due to the increased activity, leading to possible loss of body fluid. The reduction in condition factor if persistent could lead to reduction in growth rate and reproductive capacity[ [16].

The values of hepatosomatic index obtained in this study increased with the increasing concentrations of the chemicals. A similar result was obtained by Ariweriokuma et al. [16] in Clarias gariepinus exposed to cypermethrin in the laboratory. The slight increase in the liver may be due to enzymatic decontamination activities, which activate various metabolic processes, such as increased protein synthesis and lipid storage which frequently occurred in fish exposed to organochloride [30]. However, the renatosomatic index index were also elevated in the experimental fish. In fish, these organs are involved in blood production, blood filtration and immune response processes. Jenkins [31] reported that increase in RSI may be a mechanism to cope with the effect of toxicants by increasing their hemolytic capacity. The values of the spleenosomatic (SSI) and cardiosomatic index (CSI) fluctuated minimally and were within the same range in all concentrations of exposure, suggesting minimal impact on the spleen and heart by the toxicant. This results agrees with the report of Inyang et al. [32] in Clarias lazera exposed to dimethoate in the laboratory

\section{CONCLUSION}

The indices measured in the present study are useful for monitoring the long-term effects of dimethoate on fish. This study demonstrated that pesticides such as dimethoate are toxic to juveniles of H.longifilis. The study also showed that the toxicity depends on the concentrations of the chemicalfish species. The results showed that the behavioural pattern and mortality rate increased as exposure period and concentration increased. As the exposure to sublethal concentrations of dimethoate resulted in significant organosomatic changes. Based on the results, dimethoate should be prevented from accessing the aquatic environment so as to avoid contamination of the ecosystem 
Effects of Dimethoate on Condition Factor and Organosomatic Indices of Heterobranchus Longifilis (Valenciennes, 1840)

\section{REFERENCES}

[1] Aghoghovwia, O.A, Izah S.C, Miri F.A .(2018). Environmental risk assessment of heavy metals in sediment of Nun River around Gbarantoru and Tombia Towns, Bayelsa State, Nigeria. Biological Evidence, 8(3): 21-31

[2] Azmat, R., Talat, R. and Ahmed, K. (2007). The length - weight relationship. Condition factor and impact of fluoride concentration in Johnius belangerii of Arabian Sea. Research Journal of Environmental Toxicology 1(3): $138-143$.

[3] Gabriel, U.U., Obomanu, F.G and Edori, O.S (2010). Biochemical changes in hybrid catfish (Heterobranchus biodorsalis x Clarias gariepinus) treated with nuracron. Chinese Journal of Applied Environmental Biology 16(3):1-5.

[4] Ronald, W.G. and Bruce, A.B. (1990). Organosomic indices and an autopsy based assessment as indicators of health condition of fish. American Fisheries Society 8:93-108.

[5] Ogamba EN, Izah, SC, Isimayemiema F (2016). Bioaccumulation of heavy metals in the gill and liver of a common Niger Delta wetland fish, Clarias garepinus. British Journal of Applied Research, 1(1): 17 - 20.

[6] Seiyaboh E.I, Izah S.C. (2017). Review of Impact of Anthropogenic Activities in Surface Water Resources in the Niger Delta region of Nigeria: A case of Bayelsa state. International Journal of Ecotoxicology and Ecobiology, 2(2): $61-73$.

[7] Seiyaboh E.I, and Izah S. C. (2017). A Review of Impacts of Gas Flaring on Vegetation and Water Resources in the Niger Delta Region of Nigeria. International Journal of Economy, Energy and Environment, 2(4): 48-55.

[8] Ogamba EN, Izah SC, Ebiowe RG (2015). Bioconcentration of Mercury, Lead and Cadmium in the bones and muscles of Citharinus citharus and Synodontis clarias from the Amassoma Axis of River Nun, Niger Delta, Nigeria. Research Journal of Pharmacology and Toxicology, 1(1): 21-23.

[9] Akinsorotan A.M, Ajisodun A.F, Izah S.C, \& Jimoh J.O. (2019). Acute Toxicity of Paraquat Dichloride on Fingerlings of Oreochromis niloticus. International Journal of Research Studies in Biosciences, 7(1): 29 36.

[10] Inyang I.R, Thomas S and Izah, S.C. 2016a. Evaluation of activities of transfereases and phosphate in plasma and organs of Clarias gariepinus exposed to fluazifop-P-butyl. Journal Of Environmental Treatment Techniques 4(3): 94 - 97.

[11] Inyang, I.R., Kenobi, A. and Izah, S.C. 2016b. Effect of dimethoate on some selected metabolites in the brain, liver and muscle of Clarias lazera. Sky Journal of Biochemistry Research. 5(4): 63-68.

[12] Baily, H.C., Deanovic, L., Reyes, T., Kimball, K., Larson, K., Connar, V. and Hinton, D.E. 2000. Diazinon and Chlorophyrifos in urban water ways in Northern California. Env. Toxicol. Chem. 19:82 - 87.

[13] Das, S. and Gupta, Abhik. 2013. A study on acute toxicity, behaviour and growth in Indian flying barb, Esonus Dauricus (Hamilton - Buchanan) on exposure to organchlorine pesticide Endosulfan (EC35). Inter. J. Env. Sci. 3.2217-2223.

[14] Giulio, R. T. and Hinton D.E. (2008). The Toxicology of Fishes, CRC Press, Taylor and Francis Group, Boca Paton. 1071pp.

[15] Ariweriokuma, S.U., Akirotimi, O.A., \& Gabriel, U.U. (2011). Effects of Cypermethrin on condition factor and organosomatic indices of Clarias gariepinus. Journal of Agriculture and Social Research, 11(2),67-72.

[16] Lizama, M., Delos, A.P. and Ambrosio, P (2002). Condition factor in nine species of fish of the characidae family in the upper Parana river flood plain Brazil. Brazil Journal of Biology. 62:1519 - 1526.

[17] Gabriel, U.U., Uedeme-Naa, B., \& Akinrotimi, O.A. (2011). Pollutant induced altered behaviours in fish: A review of selected literature. Journal of Technology and Education in Nigeria (JOTEN), 16(1), 9-23.

[18] APHA (1985). Standard methods for the examination of water and waste water. 13th edition. APH, AWWA, WPCF. American Public Health Association Washington D.C. 1134pp.

[19] Far, M.S., Roodsari, H.V., Zamini, A., Mirrasooli, E. and Kazemi, R. (2012). Effects of Diazinon on Behavior and Some Hematological Parameters of Fry Rainbow Trout (Oncorhynchus mykiss). World Journal of Fish and Marine Sciences 4 (4): 369-375.

[20] Dogan D and Can, C. (2011). Endocrine disruption and altered biochemical indices in male Oncorhynchus mykiss in response to dimethoate. Pesticide Biochemistry and Physiology.

[21] Anderson, T., Forlin, L, Hardig, J. and Larsson A. (1988). A physiological disturbance in fish living in coastal water polluted with bleached Kraft pulp mill effluents. Canadian Journal of Fisheries and Aquatic Sciences. 45:1525 - 1536. 
[22] Gabriel, U.U. Akinrotimi, O.A., \& Ariweriokuma, S.V. (2012). Changes in metabolic enzymes activities in selected organs and tissue of Clarias gariepinus exposed to cypermethrin. Journal of Chemical Engineering, 1(2), 13-19.

[23] Ogamba, E.N., I.K.E.Ekweozor and E.R. Daka (2005). The influence of human activities on the zooplankton of Elechi Creeck Complex in the Niger Delta. Africa J. Environment Pollut. Health, 4 ()2): 31 -38 .

[24] Adeniyi, S.W.,Boyd, W.F. and Orie, K.A.(1989). Analysis of water quality parameters of tolerance ranges of warm water fish species. Vol.7: PP $103-110$.

[25] Oyoroko E, Ogamba EN (2017). Toxicity of Detergent Containing Linear Alkyl benzene Sulphonate on Some Commonly Cultured Fish Species in the Niger Delta. Journal of Environmental Treatment Techniques, 5(2), 72-77.

[26] Nte, M.E., \& Akinrotimi, O.A. (2011). Biochemical changes in black jaw tilapia Sarotherodon melanotheron) treated with sub lethal levels of industrial effluents. Advances in Agriculture, Science and Engineering Research, 1(2), 25-33

[27] Okechukwu, E.O., and Auta, J. (2007). The effects of sublethal doses of lambda - cyhalothrin on some biochemical characteristics of the African catfish, Clarias gariepinus. Petrocelli, A.D. (1985). Fundamental of aquatic toxicology methods and applications. Vol.12PP: 325 - 376.

[28] Gabriel, U.U., Akinrotimi, O.A., \& Ariweriokuma, S.V. (2012). Alterations of selected electrolytes in organs of African catfish, Clarias gariepinus treated with cypermethrin. Advances in students Research, 2(1),53-60.

[29] Memaster, M.E. Van Der Kraak, H.I., Portt, G.J, Monkittrick, C.B, Sibley, K.R; Smith, P.K; and Dixon, D.G. (1991). Changes in hepatic mixed function oxygenase (MFO) activity, plasma steroid levels and age and maturity of a white sucker (Castostomes commersoni) population exposed to bio acute Kraft mill effluent Aquatic Toxicology 21:191-218.

[30] Jenkins, J.A. (2004). Fish bioindicators of ecosystem condition at the Calcasieu estuay, Louisiana. National wetlands Rresearch Centre, USGS, Lafayette P.54.

[31] Inyang, I.R., Akio, K. and Izah, S.C. 2016c. Effect of dimethoate on lactate dehydrogenase, creatinine kinase and amylase in Clarias lazera. Biotechnological Research, 2(4): 155- 160.

Citation: Wilfred-Ekprikpo P.C." Effects of Dimethoate on Condition Factor and Organosomatic Indices of Heterobranchus Longifilis (Valenciennes, 1840)", International Journal of Innovative Studies in Aquatic Biology and Fisheries (IJISABF), vol. 7, no.1, pp. 1-6, 2021. http://dx.doi.org/10.20431/2454-7670.0701001

Copyright: (C) 2021 Authors. This is an open-access article distributed under the terms of the Creative Commons Attribution License, which permits unrestricted use, distribution, and reproduction in any medium, provided the original author and source are credited. 